IRSTI 03.21 .00

\author{
Karatayev $\mathbf{O}$. \\ Professor, Doctor, University of Kastamonu, \\ Turkey, Kastamonu, e-mail: okaratayev@gmail.com

\section{KYRGYZ FROM HEILONGJIANG (FU-YU) OF THE PEOPLE'S REPUBLIC OF CHINA}

The ethnonym «kyrgyz» is widely spread on the Eurasian space. This ethnonym is often found both in toponymy, and in hydronyms, oronyms. Nomadic Kyrgyz have long been migrating, especially in the Middle Ages, and at the same time, they made a significant contribution to the historical and cultural appearance of other people of Central, Middle Asia and adjacent territories in the process of ethnic and cultural relations. As a result of the centuries-old migration processes and ethno-cultural relations in Northeast China (Heilongjiang province), Fuyu Kyrgyz people appeared. The original culture of the most Oriental representatives of the Turkic-speaking people of the world since the middle of the twentieth century has found a keen interest on the part of historians and ethnographers. In the scientific literature, this nationality is compactly residing in the county of Fu-yu (Heilongjiang province, China), known as fu-u or fu-yu. In the total number of not more than 1500 people, the Fu-Yun Kyrgyz people call themselves «Kyrgyz», "Hergase» or "Tirtiz» only. According to the anthropological type, the Fuyui Kyrgyz - unlike the neighboring people of the manjurs, Mongols, daurs, Evenks - are light-skinned and with European features. However, among them there are white-faced Kyrgyz with red or light chestnut hair (shatens). As for the economic order, the Fu-yu Kyrgyz are primarily cattlemen (large and small cattle). It has been proved by science that the language of the Fuyui Kyrgyz people entering the Turkic branch of languages has common roots with the modern languages of the Khakas and Shorians. In addition, it is very similar to the languages of sarahugur and lobnowortsev (Baskakov, 1980:199-208). The Kyrgyz of Fuyuu County are divided into six genera: Tabhyn, Tabindyr, Chigdyr, Sandyrdyr, Byltirdy, Kurtyr or Kargaster (Kyrgyz). Initially, the resettlement of the Yenisei Kyrgyz people to the modern territory of Mongolia, and further to Manchuria began in the Yuan era during the reign of Khubilai Khan. In between the war of Chingizids (mid-Asiatic Hajdu Khan and the Chinese Khubilai Khan) in the bloody struggle in the open spaces of Kara-Corum from both sides participated and Kyrgyz. Furrier cattle breeding was a traditional type of Fui-kyi farm. They kept horses, sheep, and cows. They engaged in hunting, on which they went on horseback accompanied by dogs. From the oral traditions it is known that the Fuyu kyrgyz began to grow grain since the middle of the 19th century. The dwelling of Fuyu Kyrgyz people in the past was a yurt, but approximately in the middle of the first half of the XIX century. began to move to stationary buildings. In the past, the Fyuju Kyrgyz people wore loose clothing with long sleeves and a belt. Women wore clothes with members of Kyrgyz society wearing fox hats. The winter wardrobe consisted mainly of leather clothes, mostly of sheepskin, while rich Kyrgyz wore fox fur coats. Traditional musical instruments are similar to Khakassian homys (stringed instrument) and hobrah (kind of flute).

Key words: county Fu-yui, Kyrgyz, People's Republic of China, ethnic culture, Yenisei Kyrgyz.

$$
\begin{gathered}
\text { Каратаев О. } \\
\text { Кастомону университетінің, Аокторы, профессор, } \\
\text { Түркия, Кастомону қ., е-mail okaratayev@gmail.com } \\
\text { Қытай Хамық Республикасының, Хэйлунцзян (фу-юй) } \\
\text { провинциясындағы қырғыздар }
\end{gathered}
$$

\section{Қытай Халық Республикасының Хэйкунцзян (фу-юй)}

\footnotetext{
«Қырғыз» этнонимі еуразиялық кеңістікте кеңінен таралған. Бұл этноним топонимикада да, гидронимдер мен оронимдерде де жиі кездеседі. Көшпелі қырғыздар ежелден, әсіресе, орта ғасырларда белсенді түрде қоныс аударған, сонымен бірге олар этномәдени қарым-қатынастар барысында Орталық және Орта Азиямен шектес аумақтардың халықтарының тарихи-мәдени
} 
келбетіне елеулі үлес қосты. Солтүстік-Шығыс Қытайдағы (Хэйлуньцзян шет аймағы) ғасырлық, көші-қон процестері мен этномәдени қарым-қатынастары нәтижесінде Фую қырғыздары пайда болды. XX ғасырдың орта кезеңінен бастап, әлемнің түркітілдес халықтарының ішіндегі ең шығыстық өкілдерінің өзіндік мәдениеті, тарихшы-этнографртар тарапынан үлкен қызығушылық, тудыруда. Ғылыми әдебиетте, Фу-ю уезінде (Хэйлуньцзян шет аймағы, ҚХР) тығыз орналасқан бұл этникалық топ, «фу-ю» немесе «фу-юй» атымен белгілі. Жалпы саны 1500-ден астам аАамнан тұратын фу-ю қырғыздары өздерін «қырғыз», «хэргэз» немесе «тиртиз» деп атайды. Антропологиялық типке сай, фую қырғыздары - манжур, моңғол, даур, эвенктер секілді көрші халықтардан айырмашылығы - ақсары және еуропеоилтік бет әлпетімен ерекшеленеді. Бірақ, олардың арасында жирен немесе ашық-қоңыр шашты аққұұба қырғыздар да бар. Шаруашылық, құрылымына келетін болсак, фую қырғыздары - ең алдымен малшылар (мүйізді ірі және ұсақ қара мал). Түркі тілдер тармағының бір бөлігі болып табылатын фую қырғыздарының тілі, хакас пен шор халықтарының қазіргі тілдерімен ортақ тамыры бар екендігі ғылымда дәлелденді. Сонымен бірге, ол сары ұйғыр мен лобнор халықтары тілдірімен де өте ұқсас келеАі. Фую уезінің қырғыздары алты руға бөлінеді: Табхын, Табындыр, Чигдыр, Сандырдыр, Былтырды, Өрттыр немесе Кэргэстер (қырғыздар). Бастапқы кезде, Енисей қырғыздарының қазіргі Моңғолия аумағына, кейін Маньчжурияға қоныс аударуы Юань дәуірінде Құбылай ханның билігі кезінде басталды. Шыңғыс хан ұрпақтары арасындағы (ортаазиялық Қайду хан мен қытайлық Құбылай хан) өзара соғыстарында қырғыздар екі тараптан да Қарақорымның ашық кеңістігінде қанды күреске қатысты. Фую қырғыздарының дәстүрлі шаруашылық түрі отарлы мал шаруашылығы болды. Жылқы, қой, сиыр ұстаған. Ат пен итті бірге ілестіріп, аңшылықпен айналысқан. Ел аузындағы әңгімелерден, фую қырғыздарының бидай дәндерін XIX ғасырдың ортасынан бастап өсіре бастағаны белгілі болды. Ерте кезде фую қырғыздарының тұрғын үйлері киіз үй болды, бірақ, шамамен XIX ғасырдың бірінші жартысының орта кезінен бастап тұрақты құрылыс үйлеріне көшуге кірісті. Бұрынғы кезде фую қырғыздары ұзын жеңді, белдеуі бар бос киім киетін болған. Әйелдер кестеленген гүлді киім киетін. Әйелдер де, ер адамдар да жазда масадан қорғайтын, ақ матадан жасалған бас киім, ал қыста қозы жүнінен жасалған қалпақ киетін болған. Қырғыз қоғамының бай мүшелері түлкі терісінен бөрік киген. Қысқы киім-кешек негізінен былғары киімдерден және көбінесе қой терісінен тігі^ді, ал қырғыздардың байлары түлкі терісінен ішік киетін. Аәстүрлі музыкалық аспаптары хакастардың хомызы (ішекті аспап) мен хобраға (сыбызғы тәрізді) ұқсас болған.

Түйін сөздер: Фу-юй уезі, қырғыз, Қытай Халық Республикасы, этникалық мәдениет, енисейлік қырғыздар.

\section{Каратаев О.}

профессор, Аоктор, Университет Кастомону, Турция, г. Кастомону, е-mail: okaratayev@gmail.com

\section{Киргизы из провинции Хэйлунцзян (фу-юй) Китайской Народной Республики}

Этноним «кыргыз» широко распространен на евразийском пространстве. Аанный этноним часто встречается как в топонимике, так и в гидронимах, оронимах. Кочевые кыргызы издавна, а в особенности в средние века, активно мигрировали, и в то же время они в процессе этнических и культурных взаимоотношений внесли существенный вклаА в историко-культурный облик других народов Центральной, Средней Азии и сопредельных территорий. В результате многовековых миграционных процессов и этнокультурных взаимоотношений на Северо-Восточном Китае (провинция Хэйлуньцзян) появились фуюйские кыргызы. Самобытная культура самых восточных представителей тюркоязычных народов мира с середины XX века находит живой интерес со стороны историков-этнографов. В научной митературе Аанная народность, компактно проживающая в уезде Фу-ю (провинция Хэйлуньцзянь, КНР), известна под именем «фу-ю» или же «фу-юй». В общей численности не более 1500 человек фу-юские кыргызы называют себя не иначе как «кыргыз»,"хэргэз» или «тиртиз». По антропологическому типу фуюйские кыргызы - в отличие от соседних народностей манжуров, монголов, Аауров, эвенков - светлокожие и с европеоидными чертами лица. ОАнако среди них также встречаются белолицые кыргызы с рыжими или светло-каштановыми волосами (шатены). Что касается хозяйственного уклада, то фуюйские кыргызы прежде всего скотоводы (крупный и мелкий рогатый скот). Наукой Аоказано, что язык фуюйских кыргызов, входящий в тюркскую ветвь языков, имеет общие корни с современными языками хакасов и шорцев. Помимо этого, он очень схож с языками сары угуров и лобнорцев. Кыргызы уезда Фуюй делятся на шесть родов: Табхын, Табындыр, Чигдыр, Сандырдыр, Былтырды, Өрттыр или Кэргэстер (кыргызы). Изначально, переселение енисейских кыргызов на современную территорию Монголии и Аалее в Маньчжурию началось в эпоху 


\begin{abstract}
Юань, в период правления Хубилай-хана. В междоусобной войне чингизидов (среднеазиатского Хайду-хана и китайского Хубилай-хана), в кровопролитной борьбе на просторах Кара-Корума с Авух сторон участвова^и и кыргызы. Традиционным видом хозяйства фуюйских кыргызов было отгонное скотоводство. Они держали лошадей, овец, коров, занима^ись охотой, на которую выезжали на ^ошадях в сопровождении собак. Из устных преданий известно, что выращивать зерно фуюйские кыргызы стали с середины XIX в. Жилищем фуюских кыргызов в прошлом была юрта, но примерно в середине первой половины XIX в. они стали переходить к стационарным постройкам. В прошлом фуюйские кыргызы носили свободную одежАу с Алинными рукавами и поясом. Женщины носили одежАу с цветочными вышивками. И женщины, и мужчины носили шапку из белой ткани, защищавшую метом от комаров, а зимой шапку из меха ягнят. Богатые члены кыргызского общества носили мисьи шапки. Зимний гардероб состоял главным образом из кожаной одежды, преимущественно из овчины, в то время как богатые кыргызы носили лисьи шубы. Традиционные музыкальные инструменты аналогичны хакасскому хомысу (струнный инструмент) и хобрах (виА фмейты).
\end{abstract}

Ключевые слова: уезА Фу-юй, кыргыз, Китайская Народная Республика, этническая культура, енисейские кыргызы.

It is common knowledge that the ethnonym «Kyrgyz» is widely spread on the Eurasian space. This ethnonym is often found both in toponymy and in hydronyms. This means that the Kyrgyz have long been migrating, especially in the Middle Ages, that is, they led a nomadic way of life, and at the same time, they made a significant contribution to the historical and cultural appearance of many other peoples in the process of assimilation, metisation and ethno-cultural relations Central and Central Asia. Thus, one of the fragments of numerous and centuries-old migrations was the Fuyui Kyrgyz. The life and culture of the most oriental representatives of the Turkic-speaking peoples of the world from the middle of the twentieth century find a keen interest on the part of ethnographic historians $(\mathrm{Bu}-$ tanaev, 1990:45-37).

In August 1945, the Soviet troops defeated the Japanese imperial Kwantung Army entered the occupied territories of Manchuria (1931-1945). At the same time, reports were received from Soviet officers of Kyrgyz nationality to the headquarters of the Soviet Army about the discovery among the local population of people who called themselves «Kyrgyz» and speak a language they understood, which was subsequently reported to the Chinese side. This fact is considered one of the first references to fuyui Kyrgyz.

In academic circles, this ethnic group concentrated in the county Fu-yu, (Heyluntszyan Province, China) is known under the name «Fu-yu» or «Fu-yu.» Not exceeding in the number of $1500 \mathrm{fu}$ yui Kyrgyz refer to themselves only as «Kyrgyz», «hergez» or «tirtiz». One of the first explorers of Fuyu Kyrgyz people along with other neighboring nationalities (solons, daurs, Evens) was the Polish ethnographer Gundula Salk and the Chinese scientist Mambetakun Mambetturdu (Kyrgyz by national- ity). Their joint work was published in 1998 (Turdu, Mambet // Gundula, Salk: 1998). Earlier in 1943, a trio of Japanese scientists: Tiansun, a military doctor, He Hanging and Wu Tianhao, employees of the Dalian (Far) library, during their expedition to the occupied counties of Fuyu and Wujiazi, examined the indigenous Mongols and at the same time they gave information about local Kyrgyz. A year later, in iyule1944 g.yaponets Kiu Yuan Zengren (Qiu Yuan Zhengren) specially fitted out in Vutszyatsy to study Kyrgyz. Based on the information of his predecessors who visited the county of 1943 , he carried out a number of studies, thereby enriching the information about the Fuyui Kyrgyz. His research in 1986 was reissued under the title «Journey to the Kyrgyz». Probably the Kyrgyz in Huilongjiang would never have been mentioned without the first step taken in 1952 by Yu Yifu's article «Ji-er-ji-si Nenjiang Grassland» which prompted subsequently to ask for recognition of the status of a national minority for Kyrgyz. His article, reprinted in 1985, contains the main material on history, migration, social and political situation, culture and people's memory, language, economics, traditions and everyday life.

An invaluable contribution to the study of the Fuyui Kyrgyz was made by the Chinese Kyrgyz scholar, Professor of the Peking University of National Minorities Muhamed Hu Jenghuan (Dunganin by nationality) who, starting from 1957, produces a number of field and theoretical studies on the history, religious situation, family and domestic traditions of the Fuui Kyrgyz . Also, they have been carefully analyzed lexical, phonetic and morphological features of the language on the basis of them the collected linguistic material fuyuyskih Kyrgyz (Karataev 2003: 65).

In 1967, the famous turkologist E.R. Tenishev suggested that the language of the Fuyuan Kyrgyz 
is the relict remnant of the Yenisei Kyrgyz language, which has links with the language of the Tien Shan Kyrgyz and the languages of the Sayano-Altai region. Some information is contained in a short article of the team of authors - S.G. Skobelev, Zhang Taijiang, A.A. Shamaev, who in the 90 s of the XX century. visited Heilongjiang. This article is devoted to the generic composition of the Fuyui Kyrgyz (Zhang Taixiang, Shamaev, Skobelev, 1994: 227-233). Especially noteworthy article Khakas scientist M.A.Chertykova dedi- cated to fuyuyskim Kyrgyz Manchuria, China (Chertykov, 2005:12-14).

The scientific expedition to the Fuyi Kyrgyz in 2006 was headed by the Khakass professor V.Ya. Butanayev, who, with the involvement of historical and ethnographic material, published a monograph(Butanayev 2006: 88). He conducted a linguistic analysis, involving historical and ethnographic material, showed the ethnogenetic continuity of the Fuyui Kyrgyz and Khakass from the Yenisei Kyrgyz.

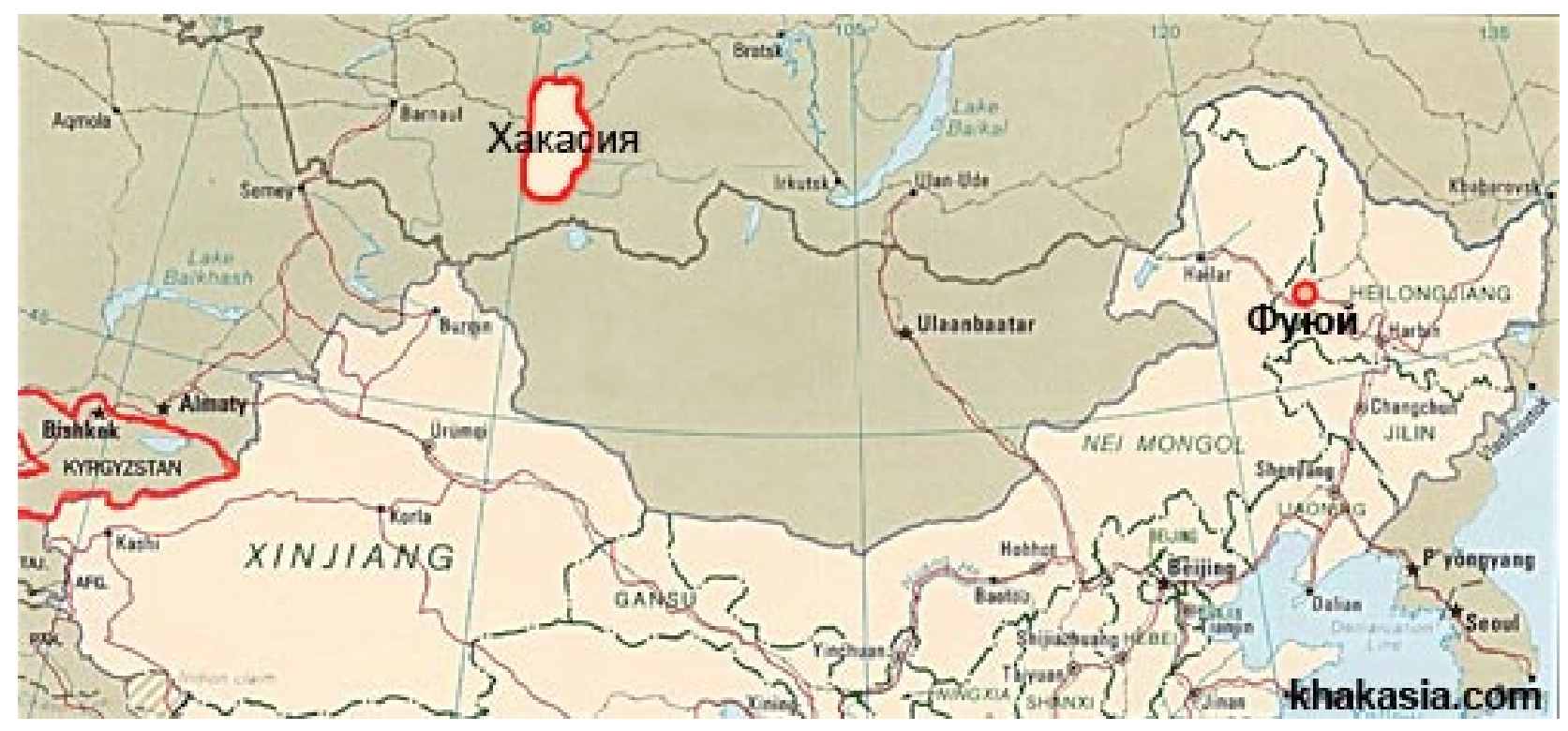

Figure

Fuyuyu County is located $300 \mathrm{~km}$ north-west of Harbin, on the left bank of the Nenjiang River in Heilongjiang Province, which occupies the northeastern part of the PRC. In the east, the county is bordered by Ian County, in the south - with Lingdian County and Qiqihar, in the west - with the outskirts of Qiqihar and is separated from the Gangan River by the river, in the north it borders on the Fanghe County. The population of the county is 270,000 people, among them: 95\% Han (Chinese), the remaining 5\% (16 thousand total) minorities Manchus, Mongols, Dungans, Koreans, Daurians, Kyrgyz, Evenki, Cibo, Miao, Chuang and 11 other ethnic groups. The older generation of Fuyui Kyrgyz identify themselves as «Kyrgyz» or «Kyrgyz», the younger generation in the Chinese dialect refers to themselves as «tirtiz» or «jilji» (Tenishev 1966: 88). Professor M. Hu Zhenhua notes that this ethnonym is translated into Chinese as «Keerkezi».
In 1947, the power of the communists was strengthened in the district; 1948 in the course of the land and water reform, the Fuyui Kyrgyz people - the native cattlemen, were forced to master land. The Fuyuy Kyrgyz are divided into several genera. The most numerous villages are in Wujiazi («five yards»). Another large settlement is located in Qi Jiaazi («seven yards»). In the process of land and water reform (1920-1930), a large number of Kyrgyz citizens of Wujiazi underwent resettlement in Tsitsizyazzy. According to the official census in 1952, 455 Kyrgyz were registered in the county of Fuyui, and in 1979 the census showed 614 people. The 1982 census indicates that 788 Kyrgyz lived in the District of Fuyuy County, 65 Kyrgyz lived in Qiqihar and about 21 Fuyui Kyrgyz were scattered outside of Manchuria. In 1990, there were 1,450 Kyrgyz in Heilongjiang. And in 2000 the number of Kyrgyz was about 1500 people (Butanaev, 2006:88) 
The indigenous inhabitants of the Mongols call the Fuyui Kyrgyz «Darno Oirat» or «Western Oirot», while the Kyrgyz call the Mongols «jun Oirat» - «Western Oirots». Despite the distance of the Kyrgyz from Manchuria from the «Turkic world», they were not subjected to the process of assimilation; moreover, they were able to preserve their ethnocultural identity. As for the language, the Fuyui Kyrgyz are bilingual. In addition, many Kyrgyz people besides the Chinese speak the Mongolian language. Obviously, this is explained by the close neighborhood and frequent mixed marriages of Kyrgyz

According to the anthropological type, the Fuyui Kyrgyz - unlike the neighboring peoples of the manjurs, Mongols, daurs, Evenks - are light-skinned and with European features. However, among them there are white-faced Kyrgyz with red or light chestnut hair (shatens). As for the economic order, the Fuhuyk Kyrgyz are primarily cattlemen (large and small cattle). As a result, meat and dairy products predominate in their diet. Especially valuable are ayran, kurut and etc (Zhang Taixiang, Shamaev, Skobolev 1994: 229).

For a long time scientific interest raises a number of questions: where is the historical homeland of the Fewy Kyrgyz people and at what time were they relocated to Manchuria? The problem of the reliability (more precisely the scientific value) of previously put forward hypotheses and theories of scientists regarding the above issues remains open.

The overwhelming majority of researchers tend to believe that the Fuyui Kyrgyz migrated to the Heilongjiang province in the eighteenth century. succumbing to political and military events. At the same time, researchers rely on historical written sources and linguistic comparisons. Some researchers believe that the catalyst for migration was the Yuan era, following the Mongol yoke, with its political decision to resettle (deport) Kyrgyz from their historic homeland.

As you know, the historical events of the SoyanAltai and Central Asia XIII century. are associated with the names of the founder of the Mongol Yuan dynasty in China, Khubilai Khan (and his heirs) and the Central Asian Chingizid Haidu Khan (and his supporters) who had a long-standing armed enmity between themselves. It is known that in the armies of each of these feuding dynasties there were Kyrgyz.

At the same time has the right to life and the second version. XVII-XVIII centuries. was one of the most dramatic historical milestones for the Yenisei and Tien Shan Kyrgyz. These are punitive expeditions of tsarist (Russian) troops to the Yenisey
«Kyrgyz state»; struggle for survival from attacks by Altan Khans; oppression of the Oirot-Kalmyks; and finally, the forced resettlement of Kyrgyz in 1708 to Zhungaria.

It has been proved by historical science that the language of the Fuyui Kyrgyz who is part of the Turkic group of languages has common roots with the modern languages of Khakas and Shorians. In addition, it is very similar to the languages of sarahugur and lobnowortsev. Thus, the Khakass linguist DI Chankov made comparisons with the commonality of the linguistic group of these ethnic groups with the Khakas-Kachin people. Khakass scientists V.Ya. Butanayev and M.A. Chertykov unanimously expressed the opinion of the similarity of the language of the Fuyui Kyrgyz with the dialects of Khakas-Sagays and Khakas-Beltirs. Earlier, the famous Turkologist Erik Tenishev noted the significant similarity of the language of the Fuyui Kyrgyz with the languages (dialects) of the Sagays, Kachins, Beltirs and Shorians (Tenishev 1966: 91). At the same time, he noted that probably the language of the Fuyui Kyrgyz was the everyday language of the Yenisei Kyrgyz in the 16th-17th centuries (Tenishev, 1997:57).

It is known that the Kyrgyz of Fuyuy County are divided into six genera: Tabhyn, Tabindyr, Chigdyr, Sandyrdyr, Byltirdy, Kurtyr or Kargaster (Kyrgyz). Recall that the names of the families of the Fuyui Kyrgyz have parallels with toponyms of the valley Mönü-Suu (Minusinsk, Khakassia), as well as a number of places in Kyrgyzstan. Thisn can be observed in the ethnonym of modern Kyrgyz. Initially, the resettlement of the Yenisei Kyrgyz people to the modern territory of Mongolia, and further to Manchuria began in the Yuan era during the reign of Khubilai Khan. In between the war of Chingizids (the Middle Asiatic Haidu-khan and the Chinese Khubilai Khan)

In the bloody struggle on the expanses of KaraCorum, the Kyrgyz also participated from both sides. Up to now, information has come that the troops of Hajdu Khan have been lodged for two years in the Minusinsk Basin. This event has led to an outbreak of epidemics of various diseases and to the moraine (famine) among the indigenous people - Kyrgyz and their kyshtym, and as a consequence to the reduction in their numbers due to increased deaths.

Historical data on the forced resettlement of Kyrgyz people to Manchuria have been preserved. In 1286, Hajdu-khan organized a large campaign in Mongolia. The prince of the Kyrgyz is not able to expose troops against the governor, he has gone through diplomacy. Finding himself in a desperate 
situation, Liu Hao-li «then bribed the thousands of a rebellious prince with clothes,» who missed the governor with a thousand people «footpaths in the mountains of Teby-Shan,» and he was able to reach China. Probably one of the reasons for the transfer of the Kyrgyz nobility to the side of Haidu was the mobilization of the Kyrgyz population and the deployment of Kyrgyz as military settlers in various regions of the empire, which threatened the dissolution of the ethnos. The situation of the military settlers was often disastrous. «In 1283 it was indicated to transfer 600 bulls, given to the rich inhabitants of Tula-Tu, the poor from the Kirghiz» (Butanaev, Khudyakov, 1999: 157).

«In 1292, Tutuha (the Kypchak commander who served Khubilai) ravaged the lands of the Altai Mountains ... He turned back on Halinga (Kara-Corum). Here he (Tutuha) was given the right to rule the Kyrgyz (jilizisis - the so-called Kyrgyz in the Yuan era). In the spring of 1293, his troops, after walking a few days along the frozen river of Qianhe, reached the Kyrgyz possessions. The army of Tutuha settled down to manage these five genera. The achievements of Tutuha are the fact that the government of the property saved him from promotion ... Khaydu sent his troops to the Qianhe River (Yenisei) to rescue the Kyrgyz (Karaev, 1983:8-99). However, Tutuha defeated his troops, and Boloch captured the commander (Kychanov, 1963: 63).

Thus, the Kyrgyz lands were again returned to the fold of the Mongolian empire Yuan. Some of the Kyrgyz from the Minusinsk Basin and from Tuva were relocated to Manzhury in the possession of the rebellious Noyan Noyon. In 1293 the genus «Usuhan, khanas, jilji (Kyrgyz)» was moved here. Under a special order, Khubilai Kyrgyz and other families were stationed in Zhaozhou as a military settlement. In 1293, addressing the Khara-batyr, Emperor Shitszu (Khubilai) said this: «the ancient lands belonging to Noyangu are named Abalha, and they will supply us with fish.» Now I built a city there, and placed the people there in three sorts. These are jun-suhani, haphanasy and jilizi (Kyrgyz). Now this city is called Zhaozhou. You now go there, and take the position of hsiangweisi (management of the region)». Another part of the Kyrgyz was placed in the «Zemetse Hasyyhe», which is also in Manchuria. In 1293, according to the order of Shih Tzu (Khubilai-khan), 700 families of the Zhirhaehusota cirrus (Kyrgyz) were placed in the lands of Hasihe as a military settlement. « In 1295, the Kyrgyz inhabiting the Jin-Shan (Altai) mountains were resettled in the Shandong region. They were allocated land, bulls and seeds (Kychanov 1963: 62).
These actions were undertaken with the aim of undermining the forces of the insurgents by transferring them to another ethnic environment and thereby controlling them. Such a policy continued even after the death of the Yuan emperor Khubilai. Historical written sources indicate that the initial stage of the forcible migration of Kyrgyz to Manchuria was the 13th century.

According to another version: it is known that in 1703 and subsequent years the Kalmyks (Dzhungary) forcibly resettled the Kyrgyz in Zhungaria. And in 1733-1736, and the subsequent 1756-1757 years. the empire of Qin (the state founded in China by the Manchus in 1644-1911) produced two migrations of Kyrgyz. The second migration of Kyrgyz was more extensive. Legends of this migration to Heilongjiang have been preserved in the folklore of the Fuyuan Kyrgyz. According to the researchers, after the Ch'ing Empire was defeated by the Zhungar Khanate, the Kyrgyz along with the Mongols moved to the present territories of Heilongjiang Province. Probably, even before this migration, the Kyrgyz already lived in the Altai-Khangai Mountains. The Kyrgyz were subjected to resettlement (deportation) and were settled in five villages of the Manchu people: Aihui, Bukui, Hailar, Bayansu and Hulan. Six kinds of Kyrgyz are specified. These are: Daben, Ekiqe, Gapuhan, Sader, Boleter, Ger'esi. Modern Fuyui Kyrgyz took the Chinese names $\mathrm{Wu}$, Hang, Chang. After that, the Kyrgyz were subordinated to the military corps with red, blue, white and orange banners.

In the historical memory of Fuhuyk Kyrgyz people the following information was preserved: «Heilongjiang Kyrgyz people originally lived in Xinjiang. When the Qin (Manchu) troops began the offensive the Kyrgyz found refuge in the cave «one hundred sacred pesher» in the Altai. They got the news that a lot of Kyrgyz soldiers were taken prisoner to the hands of the Manchus (the Qin Empire), together with the Zhungar Khan of Davatzi. After a lapse of 49 days from Emperor Qianlundang, a special letter came in which indicated that the families in which the men were captured would be united with the solos (the solons are an ethnic group). Thus, these Kyrgyz united with families moved to Heilunjiang (Chertykov, 2005: 29).

The Kyrgyz discussed above were formerly in the Zhungar «Kyrgyz Otogu» («Otok» - the name of the administrative unit of the Zhungar Khanate). «Kyrgyz Otogu» in those days was near the city of Kulzh (Inin), along the Ili river basin.

However, the Kyrgyz did not have a special social status; but, given the excellent possession of 
military art, they were enrolled in special military regiments. In addition, they were also forbidden to marry with representatives of other nations and nationalities, which eventually led to a quantitative and qualitative reduction of the Kyrgyz population. In 1949, after the communist power was established in China and the land-economic reforms began, the social situation of ethnic minorities, including number and Kyrgyz, began to improve.

According to the tribal composition, the Fuyui Kyrgyz are divided into the following genus: Tabhyns, Tabindyr, Chigdyr, Sandyrdyr, Byltirdy, Kurtyr or Kargaster (Kyrgyz). The enumerated ethnonyms common in the Khakassko-Minusinsk Basin are direct descendants of the Yenisei Kyrgyz, and are closely interconnected with modern Khakases. In 1616, the ataman of the Russian Cossacks Vasily Tyumentsev, heading for the ambassadorial service to the Altyn Khan of Mongolia, passed along the land of Tabyn, which is located in the upper reaches of Abakan. In the embassys order «Land Tabyn» - «Kirgizskaya Zemlyatsa» (Russian in the XVIIXVIII the possession of the Yenisei Kyrgyz people was called «Kyrgyz land, land») it was noted that they (Kyrgyz) pay taxes to Altyn-khanam. Today, tobaccos (among the Fuyuan Kyrgyz - «tabindyr») in the modern Beltai Khakass are known as a large clan (in Khakassia). The place where the ancestors of the tabacs lived long ago is called Taban-Chul (Taban pond). The place where they had long hunted is called «Taban-taiga» (along the river Mamur), and the place where they spent the winter - «TabanChul» (Butanaev, 1995: 117).

The genus of the Fuyui Kyrgyz «wasted» is completely in tune with the Khakass tribal group Beltir (Piltir). This ethnonym is found in the Kyrgyz generic bugu group in the form of a «bildir». Naturally this fact could not be created from scratch. Khakass historical folklore testifies that in 1703 the Khakassbeltirs (hack pilasters) were forcibly relocated to Zhungaria, thus reuniting with the ancestors of the Kyrgyz (Butanaev, 1990: 48).

The Beltirsky district of the «Kyrgyz earth» of the Altyrsky ulus in Russian written sources is known since 1635, and the genus Beltir residing there are divided into two groups «akpilatir» and «karpilattir». The generic groups Beltir are known at least since the XVII century. As a part of the Kyrgyz tribe, the bugu meets a genus named «bildir». A scientifically grounded fact, the fact that the ethnonyms of the «Piltir» style were found in remote from each other three regions testifies: Kyrgyz, Khakass and Fuhuyk Kyrgyz have common ethnogenetic origins. For example, as part of modern Khakas-Sagays, there is an ethnonym «Piltir», which in the BuryatMongolian language conveys the meaning «mixed», «heterogeneous» or «different». After a lapse of time, the ethnonym «Piltir» passes into the category of exoethonyms. It is known that today the Tuvans call the neighboring Khakass «Beldir». At the same time, the word «beltir» in the Khakas and Altaians denotes the place where the aryks, rivers and canyons merge (Baskakov, 1980: 107).

Thus, it can be understood that this ethnonymy in the language of the Yenisei Kyrgyz appeared as a designation of the tribe that appeared as a result of the fusion or unification of several genera - «a tribe created from different unified genera. «Some researchers tend to believe that the ethnonym «chigdyr» Kyrgyz is interconnected with ulus «chic», which was located in the XVII century. in the Khakassko-Minusinsk Basin, the historical homeland of the Yenisei Kyrgyz. By name with this ulus has similar parallels of a large genus «shykmat» from the Kyrgyz Sayak tribe. It has ethnical parallels and a large modern family among the Turkmen «shig». Khakass ethnographer, professor V.Ya. Butanayev notes that the name of the Sagayseok «ihege» is consonant with the name of medieval chicks - the people who lived in Tuva on the river. To the kemchik. The members of the seok lived on the river. Bai in the valley of the river. A sketch, at the foot of the tribal mountain Sakhchakh $(\mathrm{Bu}-$ tanaev, 1994: 14).

According to legend, seok «ichege» has been preserved in Khakassia since the time of the Flood. His representatives attributed themselves to the part of seok «as Khasha.» They received their name during the temporary stay in Tuva. Folklore data do not exclude the possible connection of the aforementioned seok (genus) with chicks.

Indeed, the «chik» according to the ancient runes are known as an independent people. Places where the chicks dwelt presumably were in the upper reaches of the Yenisei, and in the territory of modern Tuva. Tuva and adjacent territories in the IX. for the «Kyrgyz Kaganate» were considered a strategic springboard. Researchers note that Kyrgyz in the 9th century. lived in the neighborhood with Tannu-Olami (Petrov, 1963: 13).

Tannu-Ola was a very convenient place to rate Kyrgyz kagans. Tannu-Ola, now located in the south of modern Tuva, provided excellent opportunities for direct access to the vast expanses of Central Asia (Mongolia and adjacent territories). On the monument of Mogilyan (Bilge) kagan it is said: "When I was twenty-six, the people together with the Kyrgyz turned out to be my enemies. 
"According to this message it becomes clear that the chiki were an independent and independent people (tribe). At one time, chicks lived in the north-western territories of modern Mongolia. On the monument dedicated to the Uighur Khayan Moyun-Chur (745-759) it is said: «He sent the messengers (Karluk khan) to the Kyrgyz, calling for the rebellion of the chicks...». This historic event occurred in 751. The Uighur kahan MoyunChur gathered troops attacking the chicks, and he (kagan) managed to force them out to help the mounted Kyrgyz. As for the Karluks of the Kara Irtysh who lived in the east, they were completely defeated (Karataev, 2013: 132).

Chicks are constantly mentioned together with Kyrgyz. The scientist-encyclopedist Mahmud Kashgari: «the languages of Kyrgyz, Kyfchak (Kypchak), Oguz, Tukhsi, Yagma, Igrok, Charuk and Chigilei are originally Turkic languages»» (Koshgarii Mahmud, 1960: 66). The Kyrgyz historian O. Karaev, referring to Arabic written sources («Khudud al-Alam» - «Borders of the Universe») noted: «Hirgiz, Chigil, Hifchak, Kimak is an independent state» (Karaev, 1983: 41-42). Until the middle of the twentieth century. Among the Fuyuan Kyrgyz people, ancient pagan beliefs persisted, which were pressed with the implementation of land and water reform in China, as well as the introduction of a new communist ideology. In the historical past, there is no doubt that the Fuyui Kyrgyz came under the influence of Lamaism, but remained pagan. In the past, the Fuyui Kyrgyz had shamans («kam»). The Kyrgyz people performed rituals of worshiping ancestors and some deities, accompanied by sacrifices, especially when one of the Kyrgyz community was sick. One of the main deities was the God of the Serpent, in honor of which to the land-water reform (in Fuyu County, the land-water reform was held from 1947 to 1948). Each household usually had images, or puppet-like symbols made of cloth, many of which were serpentine and hung on the walls. In addition, the Kyrgyz every year after the New Year in midJanuary performed a ritual of burning two piles of cattle excrement, which was called «traces of wolf"s smoke.» In the past, burning «traces of wolf smoke» meant, according to the testimony of the Fuyui Kyrgyz, a signal of danger, for alerting the soldiers who saw the smoke, gathered in the designated place, and has historical roots in the combat life of the Fuhuyk Kyrgyz and Dzungar Khanate. However, after the land reform, this tradition was interrupted. In addition, there is information about the prevailing view of the prevailing «Sky-Universe» - the inexplicable heavenly universe, responsible for the eternal life of nature. The Kyrgyz understood themselves as part of the forces of nature, addressed all their hopes to the Sky-Universe. The sky-universe in the understanding of the Fuyuan Kyrgyz acted as the reason for the inexplicable and, at the same time, as the deliverer of human pain and longing, acting as the guarantor of eternity, the deliverer of eschatological fears. At the same time, the symbol of the tree with the souls of ancestors placed in it in the form of birds, acted as a symbolic link with this omnipotent authority. The funeral ceremony was accompanied by dances and singing of a shaman who, according to the views of the Fuhuyk Kyrgyz, helped the dead in a dangerous way to the afterlife.

The family-marriage tradition of the Fuyui Kyrgyz included generic exogamy, combined with ethnic endogamy. Endogamy was also supported by the Qin prohibition to marry other ethnic groups, which had a negative effect on the number of descendants, but, at the same time, it did not allow it to dissolve in an alien environment. However, a small number of Kyrgyz families did not allow full respect for the endogamous prohibitions, which was expressed in the spread of marriages between Kyrgyz and neighboring Mongolian ethnic groups (mainly with flying). There was a levirate. The marriage was arranged by the parents of the bride and groom, while they did not take into consideration the opinion of the young. Divorce was condemned as a public disgrace. For the bride the groom's side paid a ransom. Furrier cattle breeding was a traditional type of Fui-kyi farm. They kept horses, sheep, cows. They engaged in hunting, on which they went on horseback accompanied by dogs. From the oral traditions it is known that the Fuhuyk Kyrgyz began to grow grain since the middle of the 19th century (Karataev, 2013: 123). The dwelling of Fuyu Kyrgyz people in the past was a yurt, but approximately in the middle of the first half of the XIX century began to move to stationary buildings. In the past, the Fyuju Kyrgyz people wore loose clothing with long sleeves and a belt. Women wore clothes with floral embroideries. Both women and men wore a hat made of white material, which protected the summer from mosquitoes, and in the winter hat made of lamb. Rich members of the Kyrgyz society wore fox hats. The winter wardrobe consisted mainly of leather clothes, mostly of sheepskin, while rich Kyrgyz wore fox fur coats. Traditional musical instruments, apparently, are similar to Khakasshomys (stringed instrument) and hobrah (kind of flute). 
Table - Lexical parallels between the Fuyuan Kyrgyz, Kazakhs and Kyrgyz of Kyrgyzstan

\begin{tabular}{|c|c|c|c|}
\hline Fuhuyk Kyrgyz & Khakassians & Kyrgyz & $\begin{array}{c}\text { Translating to Russian } \\
\text { language }\end{array}$ \\
\hline Aal & Aal & Ayil & village \\
\hline Aar & Aar & Oor & heavy \\
\hline Aaz & Aaz & $\mathrm{Ooz}$ & mouth \\
\hline Aba & Aba & Aba, ava, ata & older brother \\
\hline Aba-iye & Aba-iche & Ata-ene & parents \\
\hline Agar & Agar & Agar, agaruu & whiten \\
\hline Agash & Agas & Zhygach, darak & tree \\
\hline Agyr & Agyr & Oruu & disease \\
\hline Agyrych & Aryg & Oruu & disease \\
\hline Ada & Ada & Ata & father \\
\hline Azakh & Azakh & Ayak,but & leg \\
\hline Ay & Ay & Ay & month \\
\hline Ayikh & Ayakh & Ayak, idish-ayak & dishes \\
\hline Aky & Acha & Aga, ake, uluuagasy & brother \\
\hline $\mathrm{Al}$ & $\mathrm{Al}$ & Al, alypkeluu & fetch \\
\hline Alakhan & Aya & Alakan & palm \\
\hline Ald & Aldy & Aldy, aldyga & ahead of \\
\hline Alton & Alton & Altymysh & sixty \\
\hline Anda & Anda & Anda, osholjakta & there \\
\hline Ang & Ang & Ang, anguloo & hunting \\
\hline Arbyn & Arbyn & Arbyn & more \\
\hline Arsylyng & Aesylan & Arstan & a lion \\
\hline Art & Art & Art & pass \\
\hline Artykh & Artykh & Artyk & superfluous \\
\hline Arshang & Arachang & Arashan, bulak & a source \\
\hline As & As & $\mathrm{Az}$ & few \\
\hline At & At & At & area \\
\hline Akhsakh & Akhsakh & Aksak & lame \\
\hline Achyk & Achykh & Achuu & bitter \\
\hline Ash & As & Ash, tamak & food \\
\hline Ash & As & Ach, achkakaluu & stay hungry \\
\hline Batyr & Matyr & Baatyr & hero \\
\hline Bakhshy & Ugretchy & Bashchy & Shaman \\
\hline Bachzha & Pacha & Bazha & brother-in-law \\
\hline Bashga & Pashkha & Bashka & Other \\
\hline Byy & Pyy & Bee & Mare \\
\hline Bil & Pil & Bel & Back \\
\hline Birge & Pirge & Birge & Together \\
\hline Bolot & Molat & Bolot & cast iron \\
\hline Bos & Pos & Bosh, erkin & Free \\
\hline
\end{tabular}


Table continuation

\begin{tabular}{|c|c|c|c|}
\hline Fuhuyk Kyrgyz & Khakassians & Kyrgyz & $\begin{array}{c}\text { Translating to Russian } \\
\text { language }\end{array}$ \\
\hline Burun & Purun & Murun & Nose \\
\hline Byltyr & Pyltyr & byltyr & last year \\
\hline Gabyrga & Khabyrga & Kabyrga & Ribs \\
\hline Gaychy & Kypty & Kaychi & Scissors \\
\hline Ganat & Kanat & Kanat & Wings \\
\hline Garool & Karool & Karool & Guard \\
\hline Gartchyga & Khartyga & Karchyga & Sacrum \\
\hline Gelerchyl & Kilerchyl & Kelerkizhyl & next year \\
\hline Gindik & Kindik & Kindik & umbilical cord \\
\hline Goy & Khoy & Koy & Ram \\
\hline Gulun & Khulun & Kulun & Foal \\
\hline Gymys & Khymys & Kymyz & Koumiss \\
\hline Gyr & Khyr & Kyr & Pass \\
\hline Gumush & Kumus & kumush & Silver \\
\hline Kysyr & Khyzyr & Kysyr & Barren \\
\hline Daa & Taа & Tayi & Uncle \\
\hline Dala & Charyn & Daly & Shoulder \\
\hline Denge & Tenge & Tenge, kumushzhasalga & Silverware \\
\hline $\mathrm{Ib}$ & $\mathrm{Ib}$ & Uy & House \\
\hline Ini, iyi & Tungma & Ini & little brother \\
\hline It & Aday & It & Dog \\
\hline Kam & Kham & Shaman & Shaman \\
\hline Kiik & Kiik & Kiyik & Deer \\
\hline Kilin & Kilin & Kelin & daughter in law \\
\hline Kirte & Kirt & Kerte & Cut \\
\hline Mal & Mal & Mal & Animal \\
\hline Nomurtkha & Nymyrkha & Zhumurtka & Egg \\
\hline Nomok & Nymakh & Zhomok & fairy tale \\
\hline Obaa & Obaa & Obootash & stone chest \\
\hline Ong & Ong & On & Ten \\
\hline Paltyr & Paltyr & Baltyr & Heel \\
\hline Pyshyr & Pyzyr & Byshyr & Cook \\
\hline Tayi & Tay & Tayi & Uncle \\
\hline Tarakh & Targak & Tarak & Combs \\
\hline Tugan & Tugan & Tuugan & Relative \\
\hline Uzun & Uzun & Uzun & a long \\
\hline Chastykh & Chastykh & zhazdyk & Pillow \\
\hline
\end{tabular}



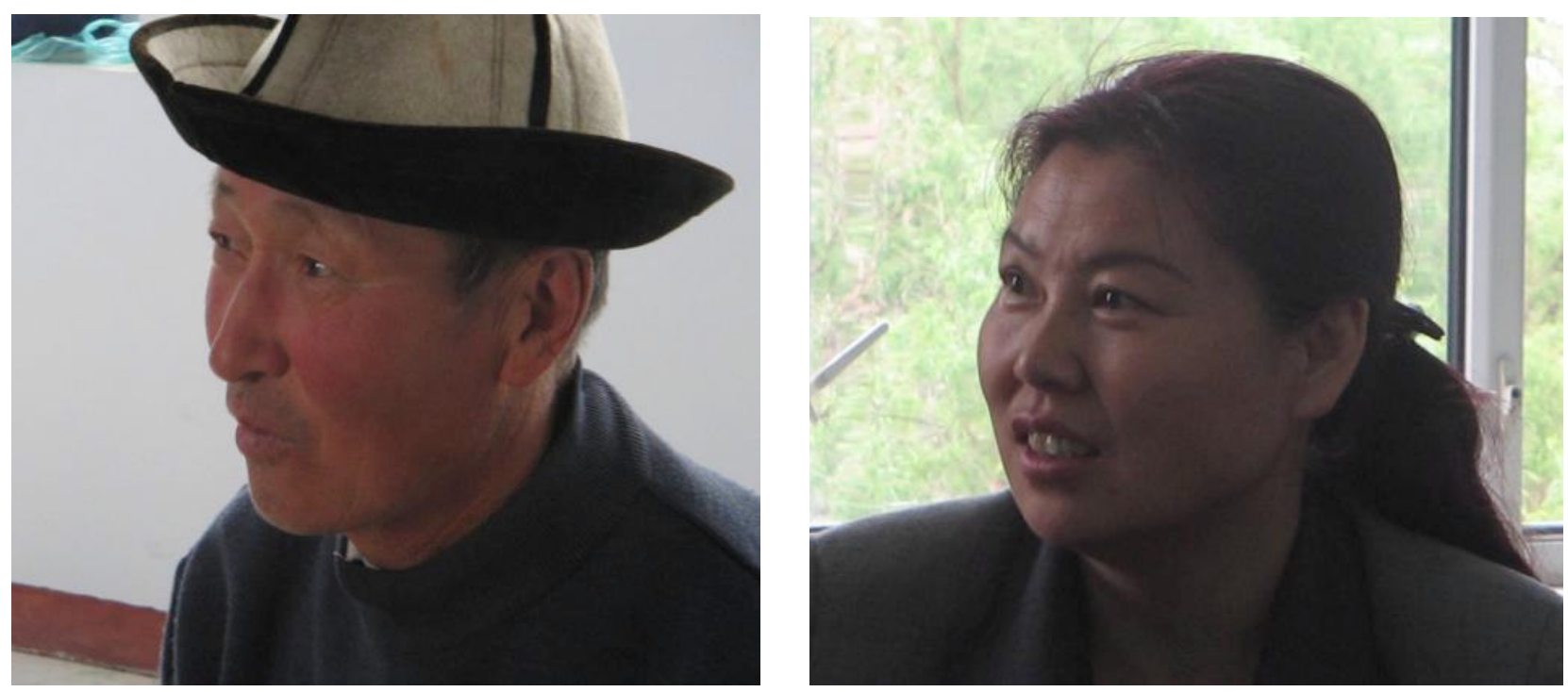

Photo 1 - Teachers of Chang and Suo, Wujiazi village. Photo by V.Ya. Butanayev
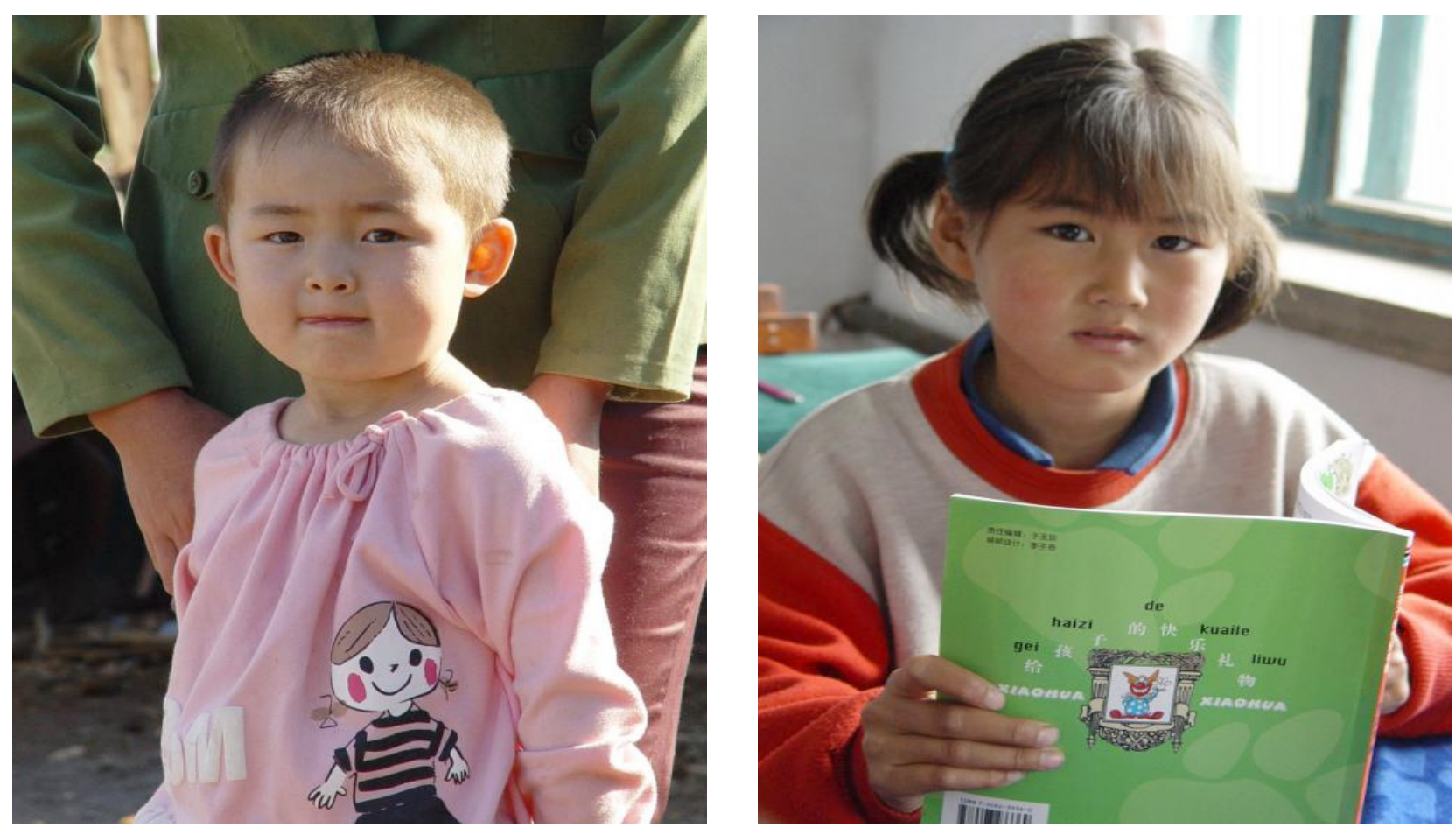

Photo 2 - Children of the Fui-Kui Kyrgyz. Photo by V.Ya. Butanayev 


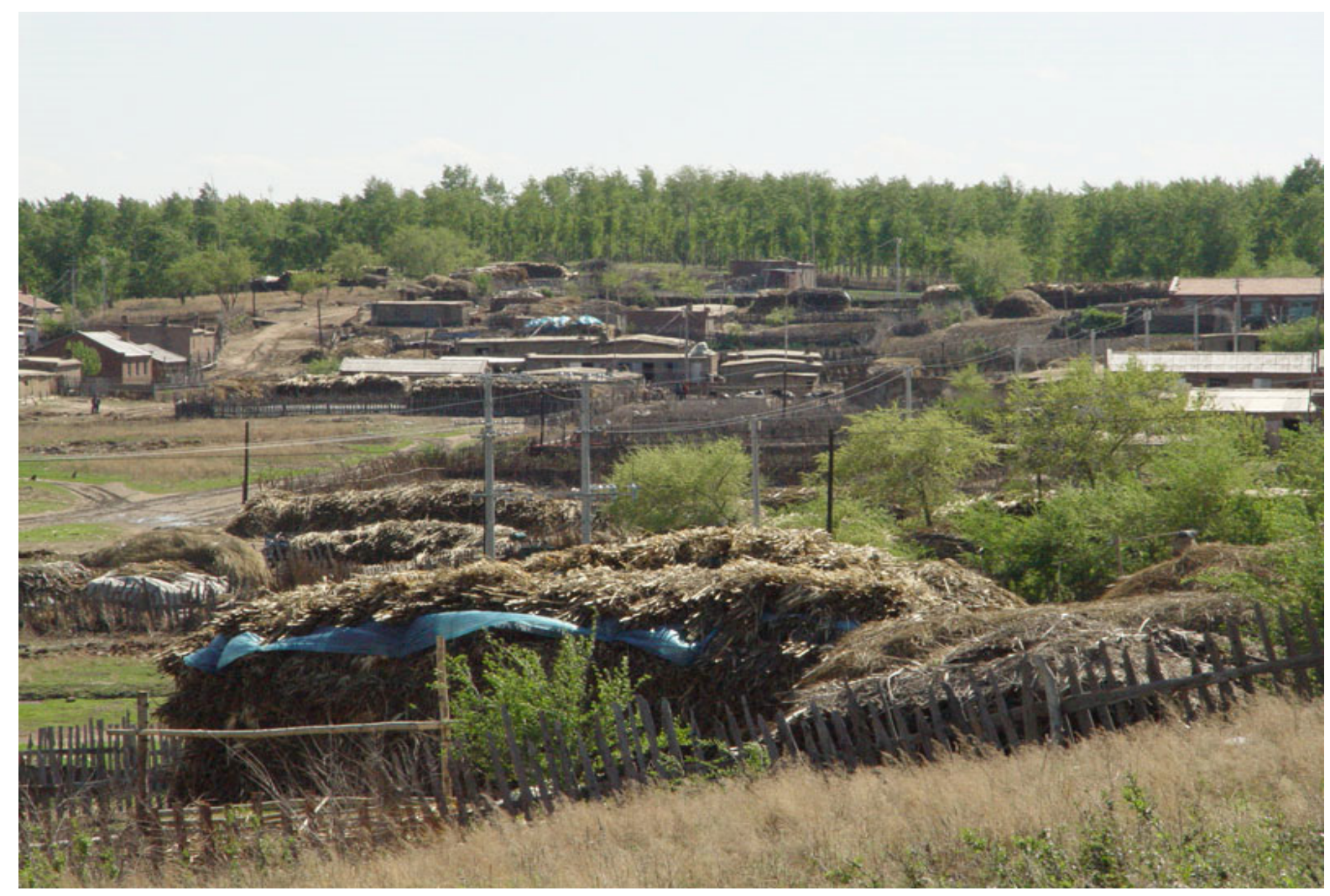

Photo 3 - The economy of the Fuyui Kyrgyz. Photo by V.Ya. Butanayev

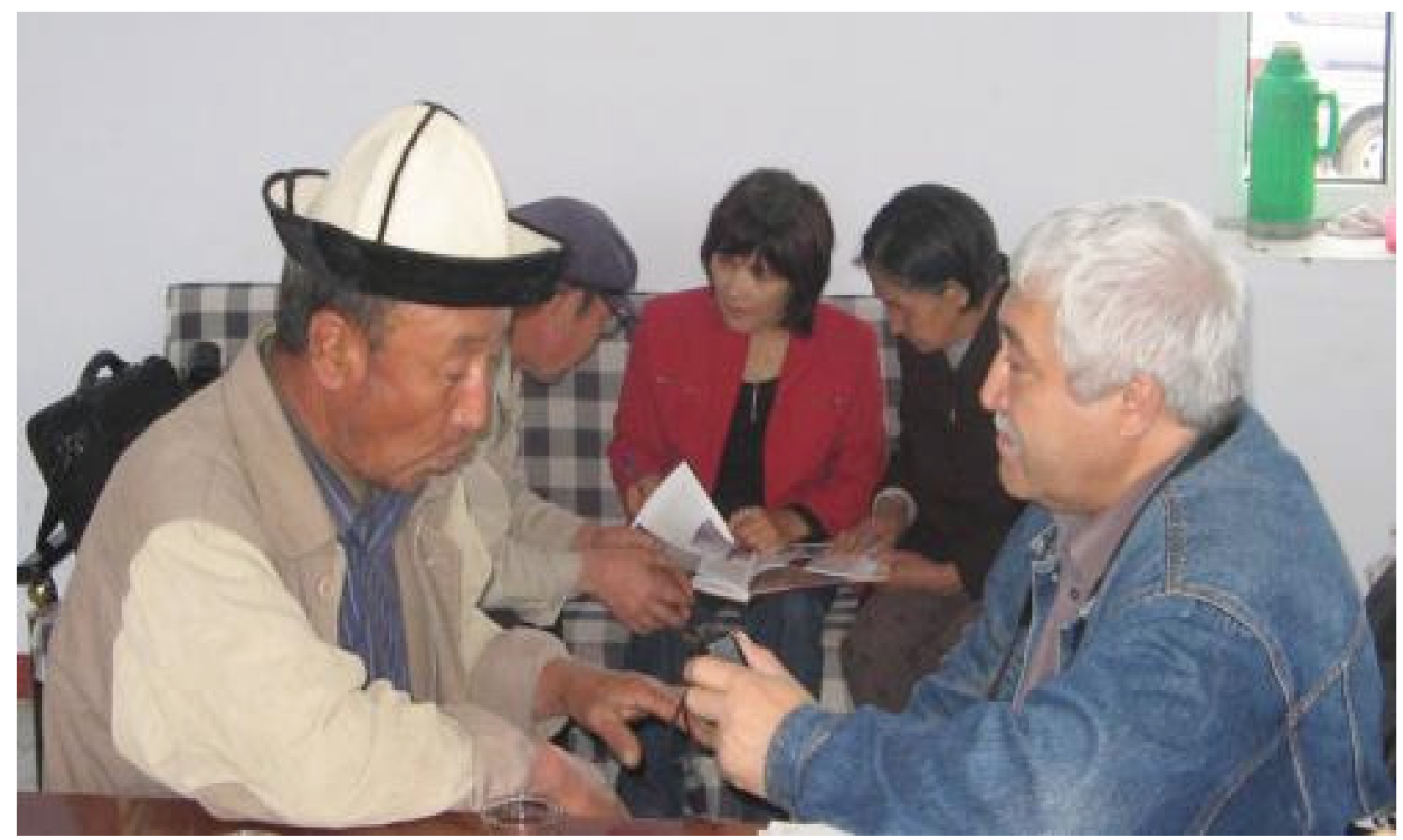

Photo 4 - The professor from Khakassia V.Ya. Butanayev in work 


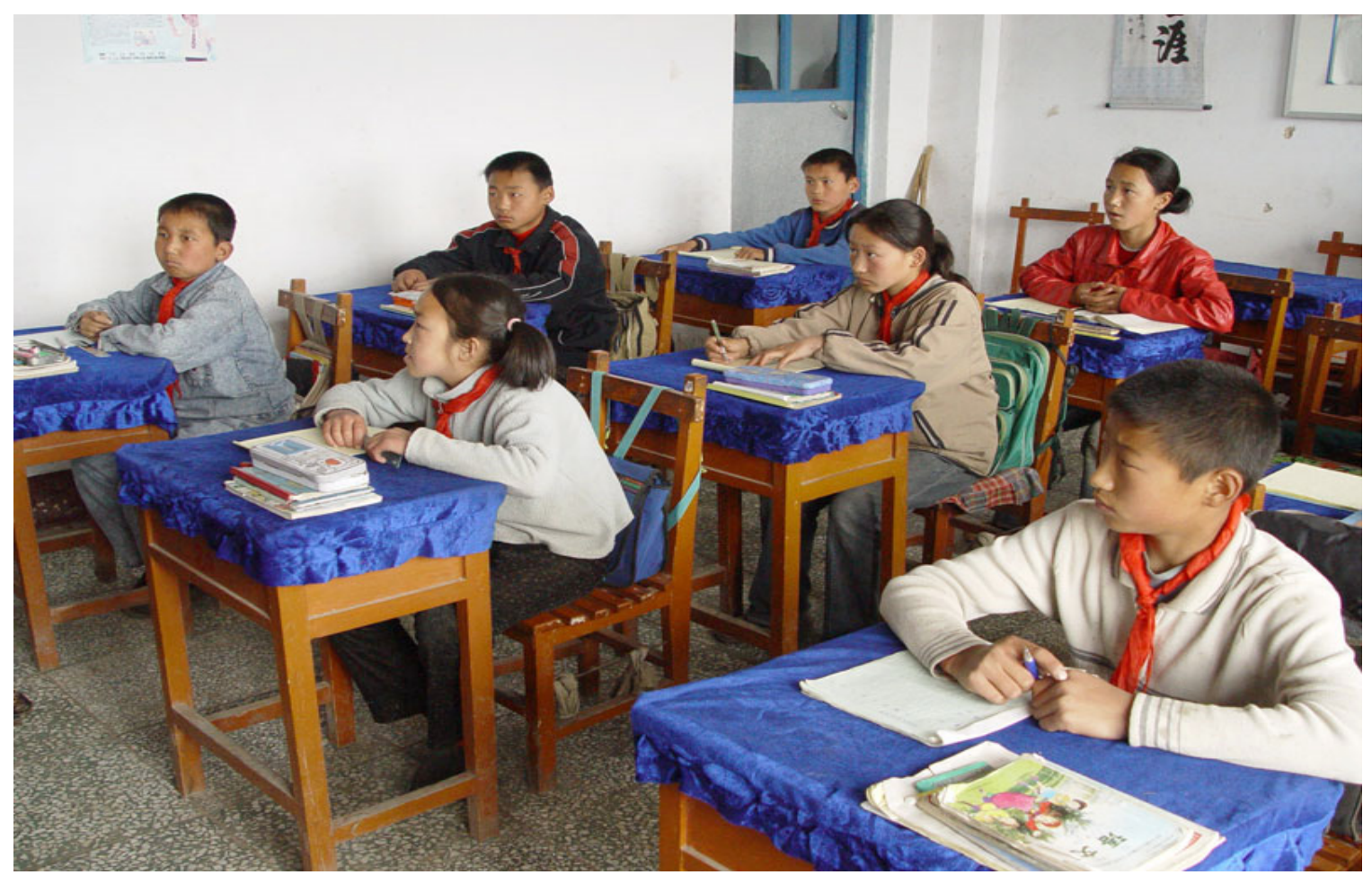

Photo 5 - Children of Fuyu Kyrgyz during the lesson at school. Photo by V.Ya. Butanaev

\section{References}

Baskakov N.A. (1980). Models of Turkic ethnonyms and their typological classification // Onomastics of the East. Moscow. ButanaevV.Ya. (1990)Ethnic history of Khakas XVII-XIX centuries. Moscow. 272 p.

ButanaevV.Ya. (2006) Khakases from Heilongjiang Province. Abakan. 88 p.

Chertkov MA (2005) Fuyuyu Kyrgyz people (historical and ethnographic essay). Abakan. 29 p.

Karaev O. (1983) Researchers on the Relations of the Yenisei and Tien Shan Kirghiz // VEIKN (Issues of the Ethnic History of the Kirghiz People). Frunze: p. 8-99.

Karataev, O.K. (2003) Kyrgyzdardyn ethnomadany bailanyshtarynyn tarykhynan. Bişkek: «Biyiktik» 267 p.

Karataev, O.K. (2013) Kyrgyzdardyn tags, kelip chygyshy, ethnostuk-madaniy alakalary. Bişkek, KTMU. 298 p.

Koshgariy Mahmud. (1967)Ivoretlugat it-turk. Index-dictionary. Tashkent. 456 p.

Kychanov E. I (1963) Information on the «Yuan-Shi» about the migrations of Kirghiz in the 13th century // Izvestiya AN Kirgiz. A series of commonly. sciences. V.V.-V.I. p. 59-64.

Petrov K.I. (1963) Essays on the origin of the Kirghiz people. Frunze, «Science». 147 p.

Skobelev SG, Jian Taixiang., Shamaev A. (1998) The species of Fuyuyu Kyrgyz people // Russia and Khakassia. 290 years of joint development. Abakan. p. 76-78.

Tenishev E.R. (1997) Ancient Kyrgyz language. Bişkek: «Kyrgyzstan». 52 p.

Tenishev E.R. (1966) On the language of the Kyrgyz of the Fuyu county (PRC) // Questions of linguistics. Moscow. № 1. FROM. p.89-95.

Turdu, Mambet (1998) GundulaSalk. The Fu-Yu Gïrgïz and their past Three stories collected in Manchuria during the Period of the Establishment of the People's Republic of China. Urumchu. -234 p. 